\title{
The effect of age on in sacco estimates of rumen dry matter and crude protein degradability in veal calves
}

\author{
L. Holtshausen and C.W. Cruywagen ${ }^{\#}$ \\ Department of Animal Sciences, University of Stellenbosch, Private Bag X1, Matieland 7602. South Africa
}

\begin{abstract}
This study was conducted to determine whether rumen dry matter and crude protein degradability in calves aged 8-10 weeks differs from that in mature cows. Five Holstein bull calves were rumen-fistulated at six weeks of age and were used in consecutive weekly $24 \mathrm{~h}$ trials from 8-20 weeks of age. Dry matter and crude protein degradability of two starter and two finisher veal calf diets of high or low rumen degradable protein content were estimated from $24 \mathrm{~h}$ in sacco incubation. Rumen $\mathrm{pH}$ and concentrations of volatile fatty acids and ammonianitrogen were determined on a weekly basis. Three rumen-fistulated Holstein cows were also used to evaluate dry matter and crude protein degradabilities of the diets. Estimates of dry matter degradability obtained from calves differed between the low and high degradability diets within weeks. Dry matter degradability differed between the starter and finisher diets (weeks 10 and 11) and remained fairly constant from week 11 to week 20. Crude protein degradability in calves also differed between the low and high degradability diets within weeks. Crude protein degradability increased up to week 12 and then remained constant until week 20. Dry matter and crude protein degradability estimates for the starter diets were both lower than the corresponding values obtained with cows, while estimates for finisher diets were similar. There were no clear trends over time for rumen $\mathrm{pH}$, volatile fatty acid concentrations and ratios, or for rumen ammonia-nitrogen concentrations ion calves. These values showed a degree of variation between weeks and were similar to literature values for mature ruminants.
\end{abstract}

Keywords: calves, protein degradability, rumen volatile fatty acids, rumen $\mathrm{pH}$, rumen ammonia nitrogen

\#Author to whom correspondence should be addressed. E-mail: cwc@maties.sun.ac.za

\section{Introduction}

Three of the metabolizable protein systems that have been proposed to replace crude protein (CP) or digestible protein to describe protein requirements for ruminants are dependent upon estimates of protein degradation (Burroughs et al., 1975; Vérité \& Jarrige, 1979). Quantitative information on the extent of protein degradation in the rumen is therefore needed. Estimates of the amount of protein escaping degradation in the reticulo-rumen are extremely variable. Part of the variation is due to analytical error and part to variation arising from feedstuffs, the diets used, feed intake, the experimental animals employed, method of feeding and the physical nature of the diet (Bull et al., 1985). In vitro incubations of feedstuffs with rumen contents (Broderick, 1978) and suspension in the rumen in non-degradable bags (Mehrez \& Ørskov, 1977) are two of the methods used for estimating dry matter (DM) and protein degradability. No single technique or experimental design, however, is fully satisfactory at the present time (NRC, 1989).

The estimates of degradability tabulated by the NRC are for a limited amount of feedstuffs and were obtained from experiments with sheep and/or cattle (NRC, 1989). The question arises as to whether these values can be used when calculating the degradability of diets for young growing calves. The extent to which they will be applicable will, in part, depend on the state of maturity of the rumen at any given age. Adequate bacterial populations in the rumen of the calf appear to be present at a very early age and subsequent development is stimulated by an increase in solid feed consumption. The earlier solid feed is introduced into the rumen, the earlier microbial development occurs, resulting in higher rumen metabolic activity (Anderson et al., 1987b). Quigley et al. (1985) reported that rumen function of weaned calves at four weeks of age was not comparable to that of mature cattle. It may take several weeks for full development of rumen function as assessed by rumen volatile fatty acid (VFA) concentrations (Quigley et al., 1985; Quigley et al., 1991; Quigley \& Bernard, 1992) and ratio of microbial nitrogen to duodenal nitrogen (Leibholz, 1975; Quigley et al., 1985). Young calves have, however, been reported to possess mature rumen function as early as two to three weeks after solid feed is first offered (Lalles \& Poncet, 1990). This study was conducted to determine whether rumen dry matter and crude protein degradability in calves aged 8-10 weeks differs from that in mature cows. 


\section{Materials and Methods}

Five Holstein bull calves and three rumen-fistulated Holstein cows were used in two degradability experiments. The five bull calves were between three and seven days of age when purchased. Feeding and housing management until weaning were the same as described by Holtshausen \& Cruywagen (2000). Calves were moved to an open pen $(10 \mathrm{~m} \times 8 \mathrm{~m})$ after weaning where they were kept until 16 weeks of age. They were housed in a section of a freestall barn during the last four weeks (weeks 16-20) of the experiment. Calves were rumenfistulated at the age of 6 weeks. Calves received starter pellets ad lib. from day seven until week 10 of the experiment and finisher pellets $a d$ lib. from week 11 until week 20. Both the starter and finisher diets consisted of a 50:50 mixture of the high (HD) and low degradability (LD) diets used in a previous trial (Holtshausen \& Cruywagen, 2000).

Dacron bags were incubated once weekly from 8 to 20 weeks of age to determine $24 \mathrm{~h}$ disappearance values. Diets were hammer-milled through a $2 \mathrm{~mm}$ screen and weighed into $100 \times 140 \mathrm{~mm}$ bags of pore size $53 \pm 2 \mu \mathrm{m}$. Approximately $4 \mathrm{~g}$ DM was accurately weighed into each bag, providing a sample to surface ratio of ca. $14 \mathrm{mg} / \mathrm{cm}^{2}$ to comply with standard procedures (Vanzant et al., 1998). Four bags, duplicates of both the high and low degradable diets, were incubated in the rumen of each calf. Bags were soaked in water $\left(39^{\circ} \mathrm{C}\right)$ for 15 minutes before incubation. Bags were suspended individually on $50 \mathrm{~cm}$ nylon lines that were fixed to the screw-in plug of the cannula. The starter diets were used during weeks 8 to 10 and the finisher diets for the remainder of the experiment. The three rumen-fistulated Holstein cows were adapted for a period of two weeks to a commercial total mixed ration for lactating dairy cows, supplemented with oat hay. Each cow received $10 \mathrm{~kg}$ of the total mixed ration and four $\mathrm{kg}$ of oat hay twice-daily during the adaptation period, as well as during the degradation trial. Bags and diets were prepared in the same way as for the calves but starter and finisher diets were incubated simultaneously and suspended on $100 \mathrm{~cm}$ nylon strings. Eight bags per cow $(2 \mathrm{x}$ LD starter, $2 \mathrm{x}$ HD starter, $2 \mathrm{x}$ LD finisher and $2 \times$ HD finisher) were incubated for $24 \mathrm{~h}$ once weekly for two consecutive weeks. After incubation, bags were placed in ice water to terminate fermentation, rinsed under slow running tap water and then machine-washed three times on a gentle cycle. Bags were dried at $55^{\circ} \mathrm{C}$ for $24 \mathrm{~h}$ and the residue analysed for $\mathrm{CP}$ content (AOAC, 1998).

Rumen content samples were taken from each calf before bags were inserted and after removal of the bags. The rumen content was strained through a double layer of cheesecloth and the $\mathrm{pH}$ of the strained rumen fluid measured immediately. Duplicate $9 \mathrm{ml}$ rumen fluid samples were preserved with either $1 \mathrm{ml}$ of a $50 \% \mathrm{H}_{2} \mathrm{SO}_{4}$ solution or $1 \mathrm{ml}$ of a $10 \%(\mathrm{~m} / \mathrm{v}) \mathrm{NaOH}$ solution for rumen ammonia-nitrogen $\left(\mathrm{NH}_{3}-\mathrm{N}\right)$ and VFA analysis, respectively. Preserved rumen fluid samples were centrifuged to remove feed particles. The supernatant fluid was stored at $-20{ }^{\circ} \mathrm{C}$ until analysed.

Data for DM and CP degradability in calves were analysed using the GLM procedure of SAS (1996) with repeated measurements. The PROFILE transformation was used to generate contrasts between degradability values of adjacent weeks. Degradability data for the cows were analysed using the GLM procedure. Linear regression functions were fitted to data of rumen VFA levels, $\mathrm{pH}$ and $\mathrm{NH}_{3}-\mathrm{N}$ using the PROC REG procedure. A quadratic regression function was also fitted in the case of $\mathrm{pH}$. Significance was declared at $\mathrm{P} \leq 0.05$ unless otherwise indicated.

\section{Results and Discussion}

DM degradability results are presented in Table 1 and illustrated in Figure 1. The DM degradability differed significantly between the HD and LD diets within every week. The only difference in DM degradability over time occurred between weeks 10 and 11 . This could be due to the change-over from starter diet evaluation to finisher diet evaluation, which also coincided with a change in the basal diet from the starter to the finisher diet. It is not clear whether the difference between week 10 and 11 can be attributed to an increased ability of calves to degrade diets or to the degradability of the diets per se.

The difference between the DM degradability estimates from cows and the mean degradability estimates from calves for week 8-10 was 9.5 and 10.0 percentage units for the LD and HD starter diets respectively. The differences for the finisher diets were smaller, viz. 3.0 and 4.2 for the LD and HD diets respectively. In both cases the estimates were higher for cows. 
Figure 1 Rumen dry matter degradability of diets containing low (LD) or high (HD) levels of rumen degradable protein in veal calves from 8 to 20 weeks of age

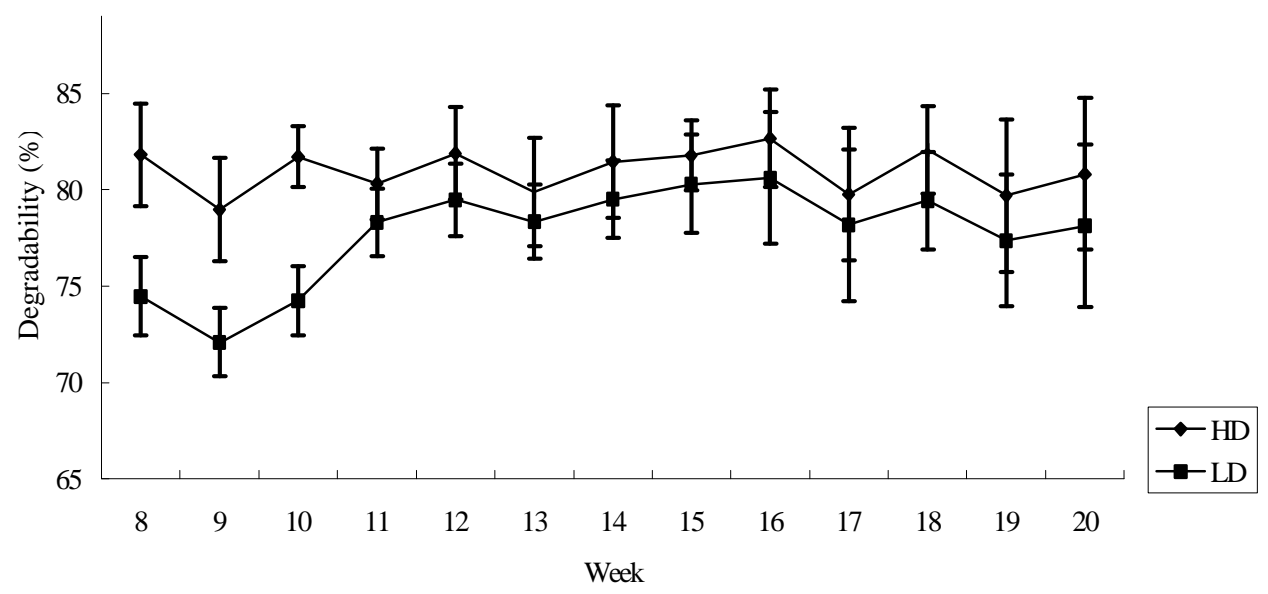

The DM degradability of the HD diet did not appear to change over time (Figure 1), while that of the LD diet tended to increase until week 11 and then remained relatively constant until week 20.

Table 1 Rumen in sacco dry matter degradability (\% of DM) of starter and finisher diets for veal calves determined in fistulated Holstein bull calves or Holstein cows

\begin{tabular}{cccccc}
\hline Week & LD & HD & SEM & P & P (contrast) \\
\hline 8 & 74.47 & 81.83 & 0.2259 & 0.0001 & 0.2763 \\
9 & 72.09 & 78.98 & 0.3348 & 0.0001 & 0.2966 \\
10 & 74.24 & 81.72 & 0.0919 & 0.0001 & 0.0001 \\
11 & 78.31 & 80.31 & 0.2835 & 0.0076 & 0.5036 \\
12 & 79.49 & 81.90 & 0.1867 & 0.0008 & 0.1063 \\
13 & 78.34 & 79.88 & 0.3537 & 0.0373 & 0.6099 \\
14 & 79.52 & 81.46 & 0.3365 & 0.0152 & 0.5543 \\
15 & 80.30 & 81.79 & 0.2772 & 0.0193 & 0.3553 \\
16 & 80.61 & 82.67 & 0.3287 & 0.0115 & 0.4290 \\
17 & 78.17 & 79.78 & 0.2110 & 0.0057 & 0.1358 \\
18 & 79.43 & 82.08 & 0.3238 & 0.0044 & 0.6776 \\
19 & 77.38 & 79.71 & 0.2828 & 0.0043 & 0.4003 \\
20 & 78.13 & 80.83 & 0.1983 & 0.0007 & \\
Mean (8- 10) & 73.60 & 80.84 & & & \\
Mean (11-20) & 78.99 & 81.04 & & & \\
Cow (Starter) & 83.06 & 90.87 & 0.4208 & 0.0001 & \\
Cow (Finisher) & 82.01 & 85.21 & 0.4208 & 0.0001 &
\end{tabular}

$\mathrm{LD}=$ Low degradable diet; HD = High degradable diet; SEM = Standard error of LS mean.

CP degradability results are presented in Table 2 and illustrated in Figure 2. CP degradability estimates obtained from calves differed significantly between the LD and HD diets for all but one week. The CP degradability of the LD diet tended to be lower during week 19. The standard error of the mean during week 19 was high compared to the other weeks, and this probably led to the lack of significance for the difference in $\mathrm{CP}$ degradability between the diets.

The South African Journal of Animal Science is available online at http://www.sasas.co.za/Sajas.html 
Figure 2 Rumen crude protein degradability of diets containing low (LD) or high (HD) levels of rumen degradable protein in veal calves from 8 to 20 weeks of age

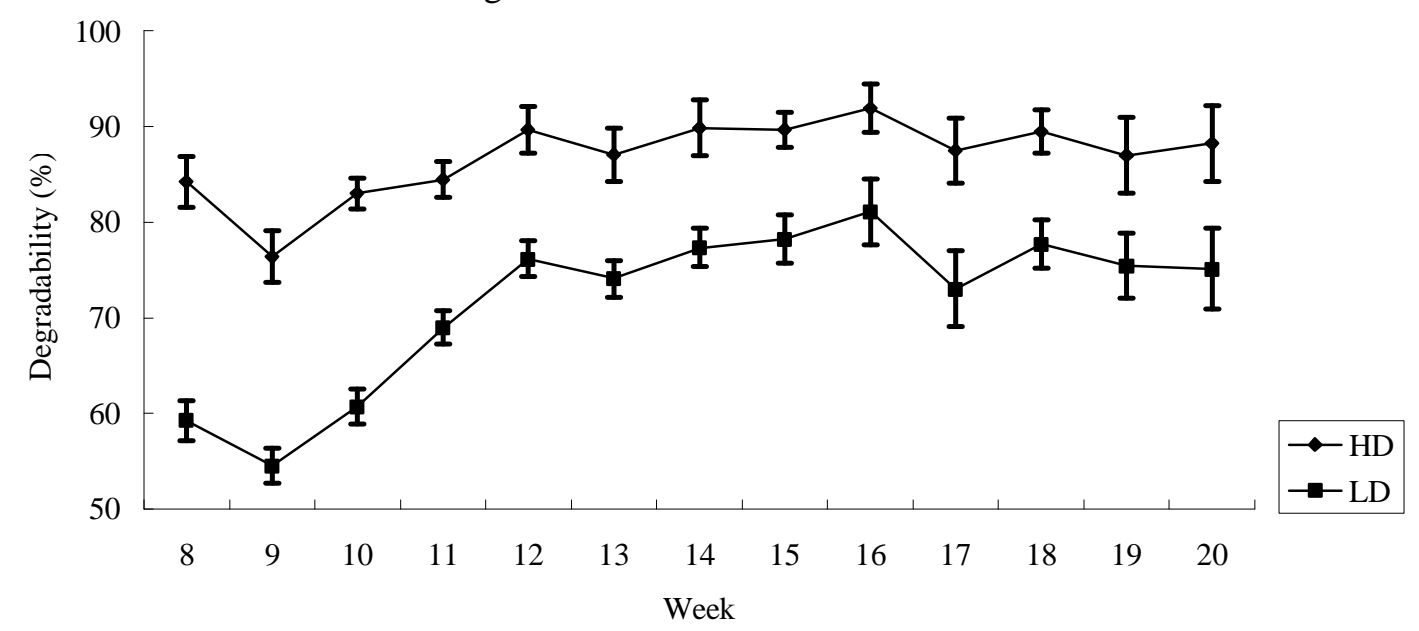

Table 2 Rumen in sacco crude protein degradability (\% of CP) of starter and finisher diets for veal calves determined in fistulated Holstein bull calves or Holstein cows

\begin{tabular}{cccccc}
\hline Week & LD & HD & SEM & P & P (contrast) \\
\hline 8 & 59.25 & 84.23 & 0.8927 & 0.0001 & 0.0405 \\
9 & 54.53 & 76.43 & 0.9172 & 0.0001 & 0.7734 \\
10 & 60.71 & 82.98 & 0.1858 & 0.0001 & 0.0007 \\
11 & 68.97 & 84.47 & 0.5801 & 0.0001 & 0.0678 \\
12 & 76.16 & 89.66 & 0.2008 & 0.0001 & 0.5684 \\
13 & 74.09 & 87.04 & 0.4843 & 0.0001 & 0.6416 \\
14 & 77.35 & 89.89 & 0.1608 & 0.0001 & 0.6262 \\
15 & 78.23 & 89.68 & 1.5668 & 0.0067 & 0.8486 \\
16 & 81.08 & 91.92 & 1.3356 & 0.0046 & 0.1630 \\
17 & 73.02 & 87.50 & 0.7918 & 0.0002 & 0.3974 \\
18 & 77.72 & 89.48 & 1.7070 & 0.0082 & 0.9752 \\
19 & 75.44 & 87.01 & 2.9790 & 0.0516 & 0.6895 \\
20 & 75.12 & 88.23 & 0.8677 & 0.0004 & \\
Mean (8-10) & 58.16 & 81.21 & & & \\
Mean (12-20) & 76.47 & 88.93 & & & \\
Cow (Starter) & 68.64 & 94.74 & 0.3945 & 0.0001 & \\
Cow (Finisher) & 73.74 & 90.53 & 0.3945 & 0.0001 & \\
\hline
\end{tabular}

LD = Low degradable diet; HD = High degradable diet; SEM = standard error of LSmean.

The difference between the CP degradability estimates obtained from cows and the mean of estimates obtained from calves during weeks 8 to 10 was 10.5 percentage units for the LD starter diet and 13.5 percentage units for the HD starter diet. The differences for the finisher diets were less, viz. 2.7 and 1.6 for the LD and HD diets, respectively. The CP degradability estimate for week 11 was omitted when calculating the mean estimate for calves because CP degradability appeared to increase until week 12. In the case of the LD diet the mean CP 
degradability estimate obtained from calves was slightly higher than that from mature cows. Vazques-Anon et al. (1993b) reported similar rates of CP disappearance for cows and calves for distillers grains and corn gluten feed, but not for soybean meal or heat treated soybean meal. This inconsistency among feedstuffs renders the cow in situ method unsuitable for the prediction of rumen protein degradability in early weaned calves.

In contrast to the temporal pattern of DM degradability, there appeared to be an increase in CP degradability for both diets over part of the experimental period (Figure 2). The CP degradability increased until 12 weeks of age and then remained fairly constant until the end of the experiment at 20 weeks of age. Both DM and CP degradability estimates were associated with time, time $\mathrm{x}$ calf and time $\mathrm{x}$ diet effects. This indicates that variation exists between calves in respect of the development of the ability to degrade feed. The time $\mathrm{x}$ diet interaction is evident from Figures 1 and 2. The DM and CP degradability estimates for the HD diet appeared to change relatively little over time, whereas $\mathrm{CP}$ degradability estimates for the LD diet appeared to increase up to the age of 12 weeks. In weaned calves, Vazques-Anon et al. (1993b) reported age, feed and feed $\mathrm{x}$ age interaction effects for the percentage of substrate remaining after $24 \mathrm{~h}$ for soybean meal, heat treated soybean meal, corn distillers grain and corn gluten feed. In contrast with results from the present study, they reported no age effect for rate of disappearance or for percentage $\mathrm{DM}$ or $\mathrm{CP}$ remaining after a $24 \mathrm{~h}$ incubation period of low-degradability feedstuffs. The rate of disappearance of high-degradability feedstuffs increased with age, and thus the percentage remaining after $24 \mathrm{~h}$ of incubation decreased.

Data on selected VFA concentrations and ratios are presented in Table 3 and illustrated in Figures 3 and 4. Concentrations of acetate, propionate and butyrate, expressed as a percentage of total VFA concentration, and VFA ratios did not differ significantly between calves. There were significant differences between weeks for all the variables. These were expressed as significant differences between several individual sets of weeks.

Figure 3 Rumen volatile fatty acid concentrations from 8 to 20 weeks of age in veal calves

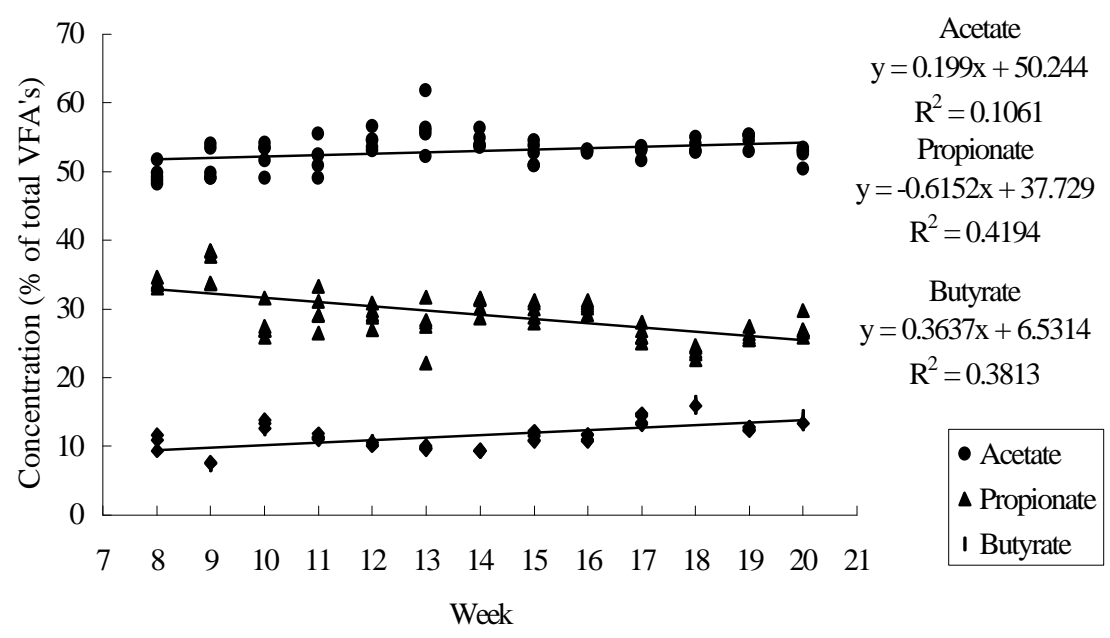

Acetate and butyrate concentrations appeared to increase slightly with age, while propionate concentration appeared to decrease (Figure 3). This is in contradiction with Anderson et al. (1987a) who reported that the molar proportion of acetate decreased and that of propionate increased with age after weaning. Regression coefficients for the linear regression functions fitted to the data were low (Figure 3). No simple non-linear relationship for the selected VFA concentrations appeared evident. Early research on VFA concentrations in the developing rumen of calves indicated an increase in total VFA concentrations with age, reaching constant levels at 6 (Lengemann \& Allen, 1959) to 8 weeks of age (Hibbs et al., 1956). Godfrey (1961) and Anderson et al. (1987a) reported constant VFA concentrations for calves from 5-17 weeks of age, although a certain degree of fluctuation was noted. Quigley et al. (1985) also reported rumen VFA concentrations indicative of mature rumen function in calves at the age of five weeks. The molar proportions of acetate, propionate and butyrate were within the normal ranges for high concentrate diets. Mature fibrous forages result in VFA mixtures containing a high proportion (70\%) of acetic acid, while diets high in concentrate result in an increase in the proportion of propionate at the expense of acetate (McDonald et al., 1988). 
Table 3 Rumen volatile fatty acid concentrations and ratios in veal calves from 8 to 20 weeks of age

\begin{tabular}{|c|c|c|c|c|c|c|}
\hline Week & Acetate & Propionate & Butyrate & $\mathrm{A}: \mathrm{P}$ & $\mathrm{A}: \mathrm{B}$ & $\mathrm{P}: \mathrm{B}$ \\
\hline \multicolumn{7}{|c|}{$(\mathrm{mol} / 100 \mathrm{~mol})$} \\
\hline 8 & 49.50 & 33.79 & 10.73 & 1.46 & 4.64 & 3.16 \\
\hline 9 & 51.11 & 36.35 & 7.48 & 1.42 & 6.84 & 4.86 \\
\hline 10 & 52.37 & 27.75 & 13.11 & 1.90 & 4.00 & 2.13 \\
\hline 11 & 52.04 & 29.76 & 11.29 & 1.77 & 4.62 & 2.64 \\
\hline 12 & 54.43 & 29.11 & 10.44 & 1.88 & 5.22 & 2.79 \\
\hline 13 & 56.35 & 27.53 & 9.76 & 2.09 & 5.78 & 2.82 \\
\hline 14 & 54.46 & 30.62 & 9.34 & 1.79 & 5.84 & 3.28 \\
\hline 15 & 52.56 & 29.74 & 11.44 & 1.77 & 4.61 & 2.61 \\
\hline 16 & 52.95 & 30.36 & 11.18 & 1.74 & 4.75 & 2.72 \\
\hline 17 & 52.93 & 26.37 & 14.11 & 2.01 & 3.76 & 1.88 \\
\hline 18 & 53.56 & 23.81 & 15.99 & 2.26 & 3.35 & 1.49 \\
\hline 19 & 54.68 & 26.12 & 12.52 & 2.10 & 4.38 & 2.10 \\
\hline 20 & 52.44 & 27.19 & 13.72 & 1.94 & 3.83 & 1.99 \\
\hline SEM & 0.7786 & 0.7925 & 0.1967 & 0.0797 & 0.1189 & 0.0928 \\
\hline $\mathrm{P}$ (calf) & 0.3783 & 0.4001 & 0.1490 & 0.3197 & 0.2028 & 0.4078 \\
\hline P (week) & 0.0001 & 0.0001 & 0.0001 & 0.0001 & 0.0001 & 0.0001 \\
\hline
\end{tabular}

$\mathrm{A}: \mathrm{P}=$ acetate to propionate ratio; $\mathrm{A}: \mathrm{B}=$ acetate to butyrate ratio; $\mathrm{P}: \mathrm{B}=$ propionate to butyrate ratio

There appeared to be a decrease in the acetate:propionate and acetate:butyrate ratios and a slight increase in the butyrate:propionate ratio (Figure 4), but the regression coefficients were low. As in the case of the VFA concentrations, there appeared to be no simple non-linear relationship for any of the selected VFA ratios over time (Figure 4). Anderson et al. (1987a) reported a decline in the acetate:propionate ratio as a result of the shift in the diet of calves from milk to fibre and starch.

Figure 4 Rumen volatile fatty acid ratios in veal calves from 8 to 20 weeks of age.
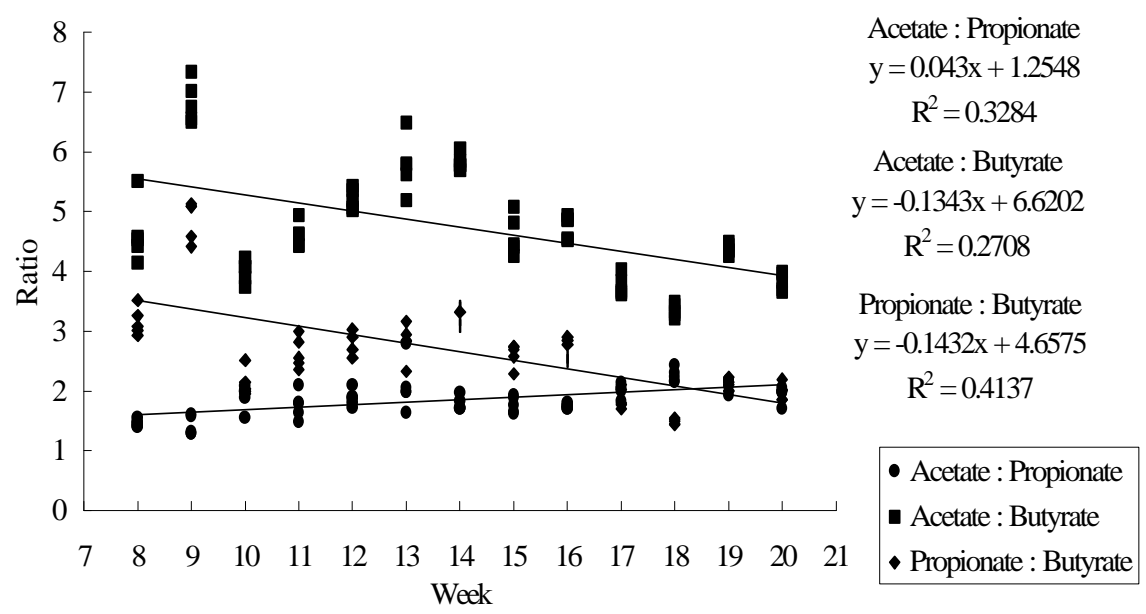

Mean rumen $\mathrm{pH}$ and $\mathrm{NH}_{3}-\mathrm{N}$ concentrations are presented in Table 4 and illustrated in Figure 5. There were no differences between calves for rumen $\mathrm{pH}$ or $\mathrm{NH}_{3}-\mathrm{N}$ concentration, but there were significant differences for both variables between several pairs of weeks. There appeared to be a quadratic response in rumen $\mathrm{pH}$ over time (Figure 5). The regression coefficient was moderate. Godfrey (1961) reported a gradual increase in rumen $\mathrm{pH}$ from 5.2 at one week of age to 6.6 at 17 weeks of age. Vazques-Anon et al. (1993a) reported a similar increase to pH 6.0 by 17 weeks of age, which is closer to the optimum for microbial proteolysis. The increase may be due to increased absorption of VFA as the rumen matures (Otterby \& Linn, 1981), or to increased salivary secretion (Anderson $e t$ al., 1987b).

There was no clear trend over time for rumen $\mathrm{NH}_{3}-\mathrm{N}$ concentration (Figure 5). There appeared to be a slight decrease in rumen $\mathrm{NH}_{3}-\mathrm{N}$ concentrations from weeks 9-20, but the variation between weeks led to a very low linear 
regression coefficient (Figure 5). Godfrey (1961) reported a rapid increase in rumen ammonia level up to five weeks of age and a subsequent gradual decrease until 17 weeks of age. Anderson et al. (1987b) and Vazques-Anon et al. (1993a) also reported a decrease in ammonia concentrations with increasing age in calves. $\mathrm{NH}_{3}$ absorption and its utilisation in the rumen are low during the first three weeks after weaning (Leibholz, 1975). The subsequent decrease in the rumen $\mathrm{NH}_{3} \mathrm{~N}$ concentration is possibly because of better utilisation of $\mathrm{NH}_{3}$ by rumen microorganisms and also because of a dilution effect arising from a greater rumen volume (Vazques-Anon et al., 1993a).

Table 4 Rumen $\mathrm{pH}$ level and $\mathrm{NH}_{3}-\mathrm{N}$ concentration in veal calves 8 to 20 weeks of age

\begin{tabular}{ccc}
\hline Week & $\mathrm{pH}$ & $\mathrm{NH}_{3}-\mathrm{N}\left(\mathrm{mM}^{\mathrm{M}}\right)$ \\
\hline 8 & 5.06 & 0.33 \\
9 & 5.07 & 2.97 \\
10 & 5.04 & 3.98 \\
11 & 5.47 & 1.98 \\
12 & 6.60 & 2.97 \\
13 & 6.55 & 2.06 \\
14 & 5.91 & 2.18 \\
15 & 6.15 & 2.77 \\
16 & 6.21 & 3.93 \\
17 & 5.75 & 1.51 \\
18 & 6.01 & 2.57 \\
19 & 5.86 & 2.16 \\
20 & 5.60 & 2.53 \\
SEM & 0.1391 & 0.0519 \\
P (calf) & 0.9791 & 0.8280 \\
\end{tabular}

Figure 5 Rumen $\mathrm{pH}$ level and $\mathrm{NH}_{3}-\mathrm{N}$ concentration in calves from 8 to 20 weeks of age

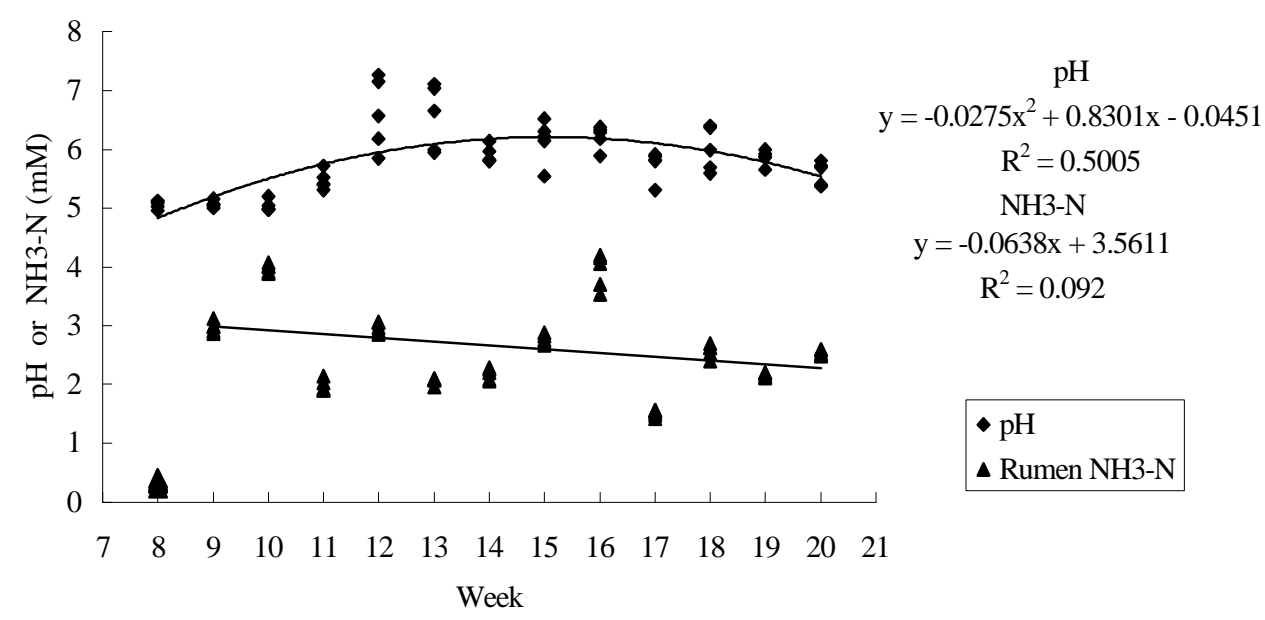

\section{Conclusion}

Results from this study suggest that DM and CP degradability in calves up to the age of 10-12 weeks differs from that in mature cows. Thereafter the ability of calves to degrade feed approaches that of mature cows. Degradability estimates obtained from experiments with mature cows should therefore not be used when calculating dietary degradability for young calves. There is a need to establish a separate database of feedstuff degradability estimates for young calves. Rumen $\mathrm{pH}$ and concentrations of VFA and $\mathrm{NH}_{3}-\mathrm{N}$ indicate that calves possess mature rumen metabolic function four weeks after weaning. The fact that calves at this stage do not degrade diets to the same extent as mature cows, suggests that mature rumen metabolic function alone does not reflect a mature ability to degrade feedstuffs. 


\section{References}

Anderson, K.L., Nagaraja, T.G. and Morrill, J.L., 1987a. Ruminal metabolic development in calves weaned conventionally or early. J. Dairy Sci. 70, 1000.

Anderson, K.L., Nagaraja, T.G., Morrill, J.L., Avery, T.B., Galitzer, S.J. and Boyer, J.E., 1987b. Ruminal microbial development in conventionally or early-weaned calves. J. Anim Sci. 64, 1215.

AOAC, 1998. Official Methods of Analysis (16 ${ }^{\text {th }}$ ed.). Association of Official Analytical Chemists, Washington, DC.

Broderick, G.A., 1978. In vitro procedures for estimating rates of ruminal protein degradation and proportions of protein escaping the rumen undegraded. J. Nutr. 108, 181.

Bull, L.S., Chalupa, W., Owens, F.N., Satter, L.D., Sniffen, C.J., Trenkle, A.H. and Waldo, D.R., 1985. Ruminant nitrogen usage. National Research Council, Subcommittee on nitrogen usage in ruminants. National Academy Press, Washington, DC.

Burroughs, W., Nelson, D.K. and Mertens, D.R., 1975. Evaluation of protein nutrition by metabolizable protein and urea fermentation potential. J. Dairy Sci. 58, 611.

Godfrey, N.W., 1961. The functional development of the calf. II. Development of rumen function in the calf. J. Agric. Sci. 57, 177.

Hibbs, J.W., Conrad, H.R., Pounden, W.D. and Frank, N., 1956. A high roughage system for raising calves based on early development of rumen function. VI. Influence of hay to grain ratio on calf performance, rumen development, and certain blood changes. J. Dairy Sci. 39:171.

Holtshausen, L. \& Cruywagen, C.W., 2000. The effect of dietary rumen degradable protein content on veal calf. S. Afr. J. Anim. Sci. 30, 204.

Lalles, J.P. and Poncet, C., 1990. Changes in ruminal and intestinal digestion during and after weaning in dairy calves fed concentrate diets containing pea or soya bean meal. 1. Digestion of organic matter and nitrogen. Livest. Prod. Sci. 24, 129.

Leibholz, J., 1975. The development of ruminant digestion in the calf. I. The digestion of barley and soya bean meal. Aust. J. Agric. Res. 26, 1081.

Lengemann, F.W. and Allen, N.N., 1959. Development of rumen function in the dairy calf. II. Effect of diet upon characteristics of the rumen flora and fuana of young calves. J. Dairy Sci. 42, 1171.

Mehrez, A.Z. and Ørskov, E.R., 1977. A study of the artificial fibre bag technique for determining the digestibility of feeds in the rumen. J. Agric. Sci. 88, 645.

McDonald, P., Edwards, R.A., Greenhalgh, J.F.D. and Morgan, C.A., 1988. Animal Nutrition (5 ${ }^{\text {th }}$ edition). Longman, Essex, UK.

National Research Council, 1989. Nutrient Requirements of Dairy Cattle ( $6^{\text {th }}$ rev. edition). Natl. Acad. Sci., Washington, DC.

Otterby, D.E. and Linn, J.G., 1981. Advances in nutrition and management of calves and heifers. J. Dairy Sci. 64, 1365.

Quigley, J.D., III, Schwab, C.G. and Hylton, W.E., 1985. Development of rumen function in calves: Nature of protein reaching the abomasum. J. Dairy Sci. 68, 694.

Quigley, J.D., III, Smith, Z.P. and Heitmann, R.N., 1991. Changes in plasma volatile fatty acids in response to weaning and feed intake in young calves. J. Dairy Sci. 74, 258.

Quigley, J.D., III, and Bernard, J.K., 1992. Effects of nutrient source and time of feeding on changes in blood metabolites in young calves. J. Anim. Sci. 70, 1543.

SAS, 1996. SAS User's Guide: Statistics, Release 6.12. SAS Inst., Inc., Cary, NC.

Vanzant, E.S., Cochran, R.C. and Titgemeyer, E.C., 1998. Standardization of in situ techniques for ruminant feedstuffs evaluation. J. Anim. Sci. 76, 2717.

Vazquez-Anon, M., Heinrichs, A.J., Aldrich, J.M. and Varga, G.A., 1993a. Postweaning age effects on rumen fermentation end-products and digesta kinetics in calves weaned at 5 weeks of age. J. Dairy Sci. 76, 2742.

Vazquez-Anon, M., Heinrichs, A.J., Aldrich, J.M. and Varga, G.A., 1993b. Effect of postweaning age on rate of in situ protein disappearance in calves weaned at 5 weeks of age. J. Dairy Sci. 76, 2749.

Vérité, R. and Jarrige, R., 1979. A new system for the protein feeding of ruminants: The PDI system. Livest. Prod. Sci. 6, 349. 